\title{
ANALYSIS OF ECONOMIC VIABILITY WITH THE USE OF MONTE CARLO SIMULATION FOR MICROGENERATION OF PHOTOVOLTAIC ENERGY
}

\author{
José Antonio de Miranda Lammoglia \\ Universidade Federal Fluminense, Brazil \\ E-mail: jalammoglia@gmail.com \\ Nilson Brandalise \\ Universidade Federal Fluminense, Brazil \\ E-mail: nilson_01@yahoo.com.br
}

Submission: $18 / 09 / 2018$

Revision: 08/11/2018

Accept: 28/11/2018

\section{ABSTRACT}

A series of public policies are being adopted worldwide to seek greater participation of renewable energy sources in the energy matrix. Brazil is a country that has a predominantly renewable energy source, with hydroelectric energy being responsible for the largest portion, but with enormous potential to be exploited for solar energy. The objective of this study was to carry out an analysis of the economic viability of a photovoltaic matrix in the distributed microgeneration model from the residential consumer perspective. Through the Monte Carlo simulation, 10.000 iterations were performed and the NPV was calculated in each of them, then counted to recover the corresponding output probability distribution and verified the NPV probability to be greater than zero. The developed method has proved to be a reliable tool to support decision making and can be applied to several scenarios. The scenario adopted for the design of the photovoltaic system presented a 95.2\% probability of returning with an NPV above zero and this makes it economically feasible. The main contribution of this paper is the replicability of the methodology used for other economic analysis studies. 
INDEPENDENT JOURNAL OF MANAGEMENT \& PRODUCTION (IJM\&P)

http://www.ijmp.jor.br

v. 10, n. 3, May - June 2019

ISSN: 2236-269X

DOI: 10.14807/ijmp.v10i3.876

Keywords: photovoltaic; microgeneration; economic viability; Monte Carlo simulation

\section{INTRODUCTION}

A series of public policies are being adopted worldwide to seek greater participation of renewable energy sources in the energy matrix. In the context of sustainability, photovoltaic energy plays a crucial role given its availability in abundance on the earth's surface.

Brazil is a country that has a predominantly renewable energy source, with hydroelectric energy accounting for the largest share, or $64.5 \%$ of all electricity generation. On the other hand, there is still an enormous potential for renewable sources of energy, especially solar energy (0,0\%) (MINISTÉRIO DE MINAS E ENERGIA, 2017). Solar energy is a source of clean energy with potential to be exploited in the country even higher than countries that are currently leaders in using that source.

The nature of the problem is: Is photovoltaic energy generation economically attractive today?

The objective of this work is to analyze the economic viability of a photovoltaic matrix in the distributed microgeneration model, and as specific objectives to raise the necessary criteria in the development of a grid tie photovoltaic project and its evaluation by economic tools that aid in decision making by determining viability from the perspective of the residential consumer.

The work presents justification as: Although the Brazilian energy matrix is predominantly hydraulic, costs for the generation, transmission and distribution of energy are not negligible, given the continental dimensions that Brazil has. In contrast to the increase in the cost of hydroelectric power, the cost of photovoltaic energy is expected to fall due to economies of scale and efficiency gains.

This work has the following organization: first part consists of the bibliographical research; data collect; market research of photovoltaic panels, accessories and equipment; project development; cost calculations for project 
INDEPENDENT JOURNAL OF MANAGEMENT \& PRODUCTION (IJM\&P)

http://www.ijmp.jor.br

v. 10, n. 3, May - June 2019

ISSN: 2236-269X

DOI: 10.14807/ijmp.v10i3.876

implementation; calculation of project amortization, and feasibility analysis of the project through Monte Carlo simulation.

\section{LITERATURE REVIEW}

\subsection{Operation of a Photovoltaic Cell}

A photovoltaic system directly converts sunlight into electricity. The basic device of this system is the photovoltaic cell. The cells may be pooled to form panels or matrices. A panel is formed by a set of cells connected to obtain large voltages and / or output currents. A photovoltaic array can be a panel or a set of panels connected in series or parallel to form large photovoltaic systems. The voltage and current available at the terminals of a photovoltaic device can directly feed small loads, such as lighting systems and DC motors. More sophisticated applications require electronic converters to process the electricity of the photovoltaic device. These converters can be used to regulate the voltage and current in the load, to control the flow of energy in grid tied systems and, mainly, to trace the maximum power point of the device (VILLALVA; GAZOLI; FILHO, 2009).

A photovoltaic cell is basically a semiconductor diode whose $p-n$ junction is exposed to light. Photovoltaic cells are made from various types of semiconductors using different manufacturing processes. Monocrystalline and polycrystalline silicon cells are the only ones found on a commercial scale today. The silicon cells are composed of a thin layer of Si connected to the electrical terminals. One side of the Si layer is doped to form the $p-n$ junction. A thin metal grid is placed on the surface of the semiconductor facing the Sun. Figure 1 illustrates the physical structure of a photovoltaic cell. The photovoltaic phenomenon can be described as the absorption of solar radiation, the generation and transport of free transporters at the $p-n$ junction and the collection of these electric charges at the terminals of the device (VILLALVA; GAZOLI; FILHO, 2009). 


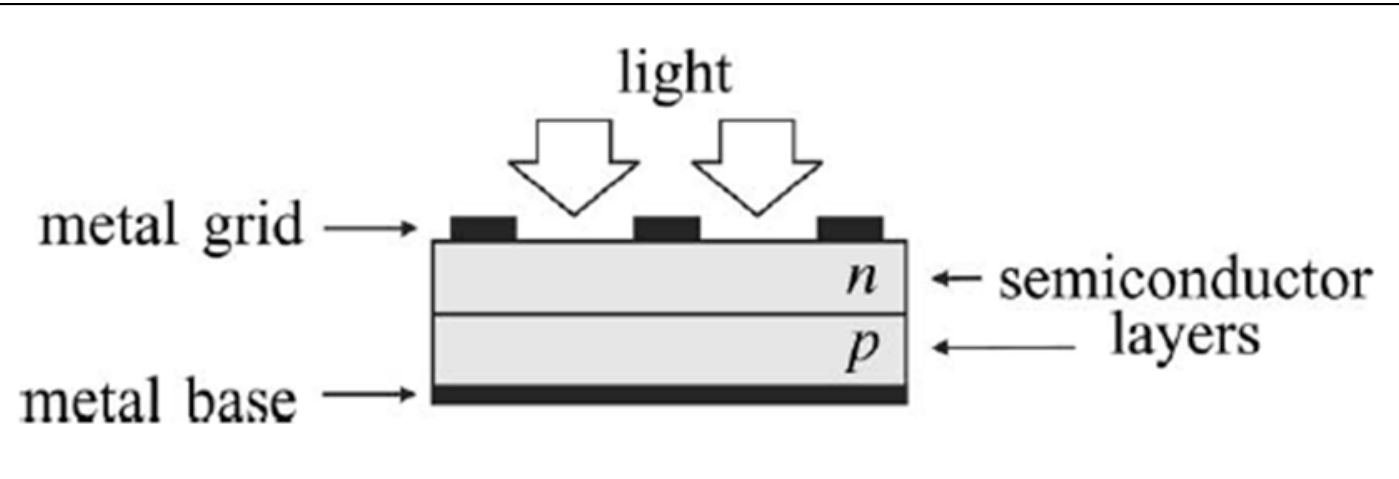

Figure 1: Physical structure of a photovoltaic cell Source: Villalva, Gazoli and Filho (2009)

\subsection{Characterization of Photovoltaic Systems}

Photovoltaic systems can be characterized in five main groups (FERREIRA et al., 2018):

\subsubsection{Grid Tie}

The grid tie photovoltaic system, usually installed in roofs and residential buildings, consists of a photovoltaic panel that converts solar energy into electricity (direct current) in which the presence of an inverter is required, which converts direct current in alternating current with voltage and frequency compatible with the standards of the electrical network to which the system is connected. The main advantages of this type of system are the high productivity, the absence of bank of battery and automatic shutdown in case of power shortage of the network, avoiding the phenomena of the isolation (ZOMER; URBANETZ; RÜTHER, 2011).

The normative resolution No. 482 of ANEEL - National Agency of Electric Energy, is the main document that regulates the operation of grid-connected photovoltaic systems in Brazil. The resolution defined the main rules for the operation of the so-called distributed micro and minigeration, a model in which small users can produce their own electricity in an integrated way to the distribution network of the concessionaires.

The resolution also defined the "energy compensation" system. This system allows the consumer to have deducted from the electricity bill the value of the amount of energy produced by the photovoltaic system. Each unit of 
INDEPENDENT JOURNAL OF MANAGEMENT \& PRODUCTION (IJM\&P)

http://www.ijmp.jor.br

v. 10, n. 3, May - June 2019

ISSN: 2236-269X

DOI: 10.14807/ijmp.v10i3.876

energy that is produced by the photovoltaic system translates into an economy of the same amount that the utility would charge to provide the consumer.

If the consumer produces more than one month of consumption, for example, the utilities will provide a credit for the extra energy produced. If the consumer has an interest in producing all the energy that he consumes, he will pay in the monthly invoice only the other expenses, almost all fixed, such as the "cost of availability", known as "minimum fee", eventual tariff flags and contribution to public lighting. Credits on energy that exceeded the consumption are valid for 60 months and can be used when the consumption is greater than the generation of energy, as in times of less insolation.

\subsubsection{Isolated}

Isolated or independent photovoltaic systems are installed in areas with difficult access to the electricity grid, generally rural areas. In this case, photovoltaic energy is the only source of electricity and some storage is needed, as in batteries.

\subsubsection{Hybrid}

Hybrid photovoltaic power generation works in conjunction with others, such as wind turbines or diesel. They are considered more complex, such systems require a control capable of integrating different forms of power generation. These systems can be connected to the network, alone or have the network support.

\subsubsection{Solar Power Plants}

These systems also connected to the grid, produce a lot of electricity in a single point. The size of the plant varies from hundreds of kilowatts and megawatts.

\subsubsection{Applied in Consumer Goods}

Photovoltaic cells can also be applied to a variety of electrical equipment such as clocks, calculators, toys, battery chargers or solar covers to charge electric cars, irrigation systems, signposting on highways, lampposts or public telephones, among others. 
DOI: 10.14807/ijmp.v10i3.876

\subsection{Investment Analysis Techniques}

\subsubsection{NPV - Net Present Value}

It's a sophisticated capital budgeting technique. It is calculated by subtracting the initial investment from the present value of the cash inflows project, which are discounted at the cost rate of company's capital (GITMAN., 2013).

$N P V=\sum_{t=1}^{n} \frac{F C_{t}}{(1+k)^{t}}-I_{0}$

Where:

$F C_{t}$ - present value of cash receipts;

$I_{0}$ - initial investment;

$k$ - discount rate (equal to cost of company capital);

$t$ - discount time of each cash inflow;

$n$ - discount time from last cash flow.

\subsubsection{IRR - Internal Rate of Return}

It is the discount rate that equates the NPV of an investment opportunity to zero (this is because the present value of the cash inflows equals the initial investment). It is the compound annual rate of return that the company will obtain, if it applies resources to a project and receives the expected cash inflows (GITMAN., 2013).

$0=\sum_{t=1}^{n} \frac{F C_{t}}{(1+I R R)^{t}}-I_{0}$

Where:

$F C_{t}$ - present value of cash receipts;

$I_{0}$ - initial investment;

$t$ - discount time of each cash inflow;

$n$ - discount time from last cash flow.

\subsection{Monte Carlo Simulation}


INDEPENDENT JOURNAL OF MANAGEMENT \& PRODUCTION (IJM\&P)

In the construction of the first atomic bomb, the Monte Carlo simulation method originated during World War II throughout the research in the Los Alamos laboratory. It was proposed by Von Neumann and Ulam for the solution of mathematical problems that were not viable through analytical treatment. Initially, it was intended for the evaluation of multiple integrals for the study of neutron diffusion. Then it was found that it could be applied to other more complex mathematical problems of a deterministic nature. The name Monte Carlo was adopted by the fact of the presence of randomness remember games of chance in allusion to the famous casino of Monaco founded in 1862, besides reasons of secrecy (BRANDALISE; CARDOSO, 2010).

Monte Carlo simulation is a probabilistic approach that allows uncertainty to be considered when calculating the expected value, that is, to assess what can happen and how it is likely to occur. Using probabilistic distributions for the main input parameters involved in the analysis, it is possible to retrieve the resulting value as a probability distribution, from which uncertainty information can be derived using common statistical methods. Each Monte Carlo iteration consists of sampling at random values from the given input distributions and computing the corresponding result (PILLOT; DE SIQUEIRA; DIAS, 2018).

Another definition for Monte Carlo simulation is the random generation of numbers by means of algorithms using probability distribution functions to obtain specific results on the process or object being studied. It can be used in problem solving in several areas of science. The main idea of the Monte Carlo simulation is that the extensive repetition of a random sampling process allows a sufficiently large and random sample space to be obtained for statistical inference.

This random sampling is essential to simulate mathematically modeled real systems, and also applies this statistical methodology to the concept of measurement variability and uncertainty because it allows the generated results to vary within a range determined by the algorithm as if they were random error fluctuations. The algorithms used in Monte Carlo methods are simple and have the ability to reduce the complexity of mathematically modeled systems (ROMERO; LOURENÇO, 2017). 
INDEPENDENT JOURNAL OF MANAGEMENT \& PRODUCTION (IJM\&P)

http://www.ijmp.jor.br

v. 10, n. 3, May - June 2019

ISSN: 2236-269X

DOI: 10.14807/ijmp.v10i3.876

\subsection{Criteria for Decision Making}

For the aid in the decision making of investments in photovoltaic projects, it is necessary to have a clear image of the criteria in the elaboration of the cash flow (DONG; XU; LIN, 2017):

\subsection{1. a) Local Insolation Conditions}

The performance of the photovoltaic module is highly dependent on the availability of solar radiation and temperature of photovoltaic cells. This factor determines whether the investment will be effective or not and will directly affect the daily generation capacity, but this depends on the nature and can not be changed at will. In this context, investments are mainly made in areas with good solar condition.

\subsubsection{Real Available Area}

The amount of solar panels depends on the actual area available, whether it is on a roof or an open area and directly influences the daily generation capacity of the system. A high wall at the edges of the roof, surrounding buildings and etc. can reduce the available area. Given this situation, the site must be accurately evaluated, based on the amount of solar panels required, in the condition of local sunlight and suitable installation angle.

\subsubsection{Local Electricity Price}

This factor has a direct impact on the output value. The price is determined by generation, transmission and distribution costs by region.

\subsubsection{Interest Rate on Loans}

Financial support is needed for almost all investment projects. To this end, some financial institutions have established specific departments to finance photovoltaic projects.

\subsubsection{Installation Cost}

This factor represents the largest proportion of investment, there is cost of design, cost of equipment, cost of labor and administrative cost. This factor is inversely proportional to the scale effect, that is, the larger the project scale, the 
INDEPENDENT JOURNAL OF MANAGEMENT \& PRODUCTION (IJM\&P)

http://www.ijmp.jor.br

v. 10, n. 3, May - June 2019

ISSN: 2236-269X

DOI: 10.14807/ijmp.v10i3.876

lower the installation cost will be, when calculated with the installed capacity per Watt. The increased production of photovoltaic products in recent years has reduced the cost of the equipment considerably.

\subsubsection{Cost of Operation and Maintenance}

This factor is included in the annual operating expense of power generation to cover periodic maintenance, surface cleaning of photovoltaic panels and other maintenance costs.

\subsubsection{Tax Subsidy}

It is a component to promote the development of distributed photovoltaic systems and considerable source of revenue. Different local subsidy policies, such as subsidies based on generation capacity and difference between retail and national electricity tariffs to encourage local investments under the circumstance of solar radiation under different conditions. These subsidies are an important way for investors to recover costs very soon, to control capital risk and shorten the payback period.

\subsubsection{Taxes}

One of the major barriers related to Resolution 482/2012 was related to the collection of ICMS under the "Electric Energy Compensation System." The ICMS - Tax on Circulation of Goods and Services in turn is a State tax applicable to electric energy (OLIVEIRA, 2016).

Law 13.169, in its art. 8, reduced to zero the rates of the Contribution to the Social Integration Program (PIS) and the Program for the Formation of Civil Servants' Equity (PASEP) and the Contribution for Social Security Financing COFINS incident on the energy injected into the network by the micro and minigerators. Then the Finance Policy Council (ConFaz) issued a new agreement (16/2015) and authorized some states to charge ICMS only on the difference between the energy consumed and the energy injected into the network by the consumers.

\subsubsection{Degradation of Photovoltaic Modules}


INDEPENDENT JOURNAL OF MANAGEMENT \& PRODUCTION (IJM\&P)

http://www.ijmp.jor.br

v. 10, n. 3, May - June 2019

ISSN: 2236-269X

DOI: 10.14807/ijmp.v10i3.876

One of the most important features of photovoltaic modules is their long life cycle, which can reach 30 years. However, recent work has proven that photovoltaic modules can suffer significant degradation before that time (BASTIDAS-RODRIGUEZ et al., 2017) and factors such as hot and humid climate considerably increase the degradation of photovoltaic modules (HUANG; WANG, 2018).

\section{METHODOLOGY AND METHODS}

For this study, the system was designed with no restricted area available for an average monthly energy demand of $350 \mathrm{kWh}$, located in the city of Volta Redonda, in the interior of the state of Rio de Janeiro (Latitude - $22.523055^{\circ}$ South and Longitude $-44.104166^{\circ}$ West), where the minimum solar radiation at full sun is 4,32 hours per day and occurs in the month of July. The minimum solar radiation is used to scale the entire system so that it can guarantee the total energy supply of the residence and was obtained through the program SunData v 3.0 in June 2018.

The system works connected to the network, as it does not exist difficulties in the supply of energy by the concessionaire. The surplus energy generated in other months of the year and radiation in the hours without full sun are used as safety margin for efficiency losses due to degradation of the solar panels and the generation of credits through the energy compensation system, guaranteed by Normative Resolution No. 482 of ANEEL. The equation used to size the number of solar panels follows below:

$n_{p}=\frac{E_{m}}{P_{p} \times h_{f s} \times w_{e f} \times s_{e f}}$

Where:

$n_{p}$ - number of solar panels

$E_{m}$ - monthly energy demand

$P_{p}$ - maximum panel power

$h_{f s}$ - hours of full sun

$w_{\text {eff }}$ - wire efficiency

$s_{\text {eff }}$ - system efficiency 
This system eliminates the need for a battery bank for energy storage, providing a lower initial and periodic investment need since the batteries have a shorter life span than panels and need to be changed a few times during the life of the project. The sizing proposed in this study presents an initial investment, and this value varies with an increase of up to $25 \%$ for the simulation, respectively the minimum and maximum values, $R$ \$ 16.852,00 and $R$ \$21.065,00.

The energy supply is made by Light Serviços de Eletricidade SA, which has three possible tariffs divided as follows: green flag, yellow flag and red flag, which can be practiced depending on the period of the year, the condition of the reservoirs of hydroelectric power plants, consumption profile and etc. and are used in this study for the simulation. As the system is located in the state of Rio de Janeiro and it is part of the CONFAZ agreement (16/2015) and is supported by Law No. 13.169, in addition to the project being designed to be self-sufficient and to operate in the energy compensation system, the collection of ICMS, PIS / Pasep and COFINS is zero.

In this study a discount rate of $10 \%$ per year was used considering that the capital is its own. The minimum shelf life of panels of 12 years, maximum of 20 years and the most probable of 18 years due to environmental conditions. The annual degradation of the modules is already considered in the design of the system because it generates surplus energy to compensate for these losses during the life cycle of the equipment.

Analyzes and calculations were performed using Microsoft Office Excel software, as their use facilitates calculations and random numbers are guaranteed for randomness, independence, that the value is uniformly distributed and nonrepetition of sequences.

For the Monte Carlo simulation, we considered 10.000 iterations, resulting in so many results. Each NPV value was calculated and then counted to retrieve the corresponding output probability distribution. That is, after the 10.000 iterations the probability of the NPV was verified to be greater than zero.

\section{RESULTS}


In order to meet the monthly demand of $350 \mathrm{kWh}$, the minimum monthly amount of radiation hours in the full sun, which occurs in July in the city of Volta Redonda-RJ, was used as can be seen in Table 1.

Table 1: Daily amount of hours in full sun in Volta Redonda-RJ

\begin{tabular}{lc}
\hline \multicolumn{1}{c}{ Month } & Full Sun (hours/day) \\
\hline January & 5,08 \\
February & 5,66 \\
March & 5,03 \\
April & 4,9 \\
May & 4,41 \\
June & 4,37 \\
July & 4,32 \\
August & 5,13 \\
September & 4,84 \\
October & 4,84 \\
November & 4,60 \\
December & 5,07 \\
\hline \multicolumn{2}{c}{ Source: SunData $\mathbf{v} 3.0(2018)$}
\end{tabular}

To meet the required power demand with the availability of defined solar radiation of 4.32 hours per day, the amount of solar panels can be seen in the calculations below, and the required calculated investment can be seen in the details shown in Table 2.

$n_{p}=\frac{E_{m}}{P_{p} \times h_{f s} \times w_{e f} \times s_{\text {ef }}}=\frac{350 \frac{\mathrm{kWh}}{\mathrm{month}} \div 30 \text { days } \times 10^{\mathrm{a}}}{330 \mathrm{~W} \times 4,32 \frac{h}{\text { day }} \times 0,98 \times 0,95}=8,79$ panels

Table 2: Breakdown of Investment

\begin{tabular}{lcccc}
\hline \multicolumn{1}{c}{ Itens } & Amount & $\begin{array}{c}\text { Unit Value } \\
(\mathrm{R} \$)\end{array}$ & Total (R\$) & $\begin{array}{c}\text { Participation in Total } \\
\text { Cost (\%) }\end{array}$ \\
\hline Solar Panel 330 Wp & 9 & 689,00 & $6.201,00$ & $36,80 \%$ \\
Installation service & 1 & $3.000,00$ & $3.000,00$ & $17,80 \%$ \\
Grid-Tie Inverter & 1 & $4.149,00$ & $4.149,00$ & $24,62 \%$ \\
String Box & 1 & 752,00 & 752,00 & $4,46 \%$ \\
Support for modules & 9 & 250,00 & $2.250,00$ & $13,35 \%$ \\
Miscellaneous (wiring & 1 & 500,00 & 500,00 & $2,97 \%$ \\
and etc.) & & & $16.852,00$ & $100 \%$ \\
Total System Cost & & &
\end{tabular}

Source: Prepared by the authors (2018)

The parameters raised and used in the Monte Carlo simulation are presented in Table 3.

Table 3: Parameters for simulation

\begin{tabular}{lccc}
\hline \multicolumn{1}{c}{ Parameters } & Minimum & More probable & Maximum \\
\hline Useful Life (years) & 12 & 18 & 20 \\
Discount rate & $10,00 \%$ & $12,00 \%$ & $22,36 \%$ \\
Total System Cost $(\mathrm{R} \$$ ) & $16.852,00$ & - & $21.065,00$ \\
Consumption (kWh / & 350,00 & - & 384,91
\end{tabular}


INDEPENDENT JOURNAL OF MANAGEMENT \& PRODUCTION (IJM\&P)

http://www.ijmp.jor.br

v. 10, n. 3, May - June 2019

ISSN: 2236-269X

DOI: 10.14807/ijmp.v10i3.876

month)

Fixed cost (R\$ / month) $\quad 30,00 \quad 40,00 \quad 50,00$

Electric tariff (R\$/ kWh) $\quad 0,91321 \quad 0,92860 \quad 0,96035$

Source: Prepared by the authors (2018)

With the parameters raised, it was possible to calculate the NPV of the project and, after 10.000 iterations, an average of $\mathrm{R} \$ 6.175,73$ was calculated, median of $\mathrm{R} \$ 6.199,60$ and standard deviation of $\mathrm{R} \$ 3.716,48$. The values of NPVs found were normally distributed according to the graph shown in Figure 2.

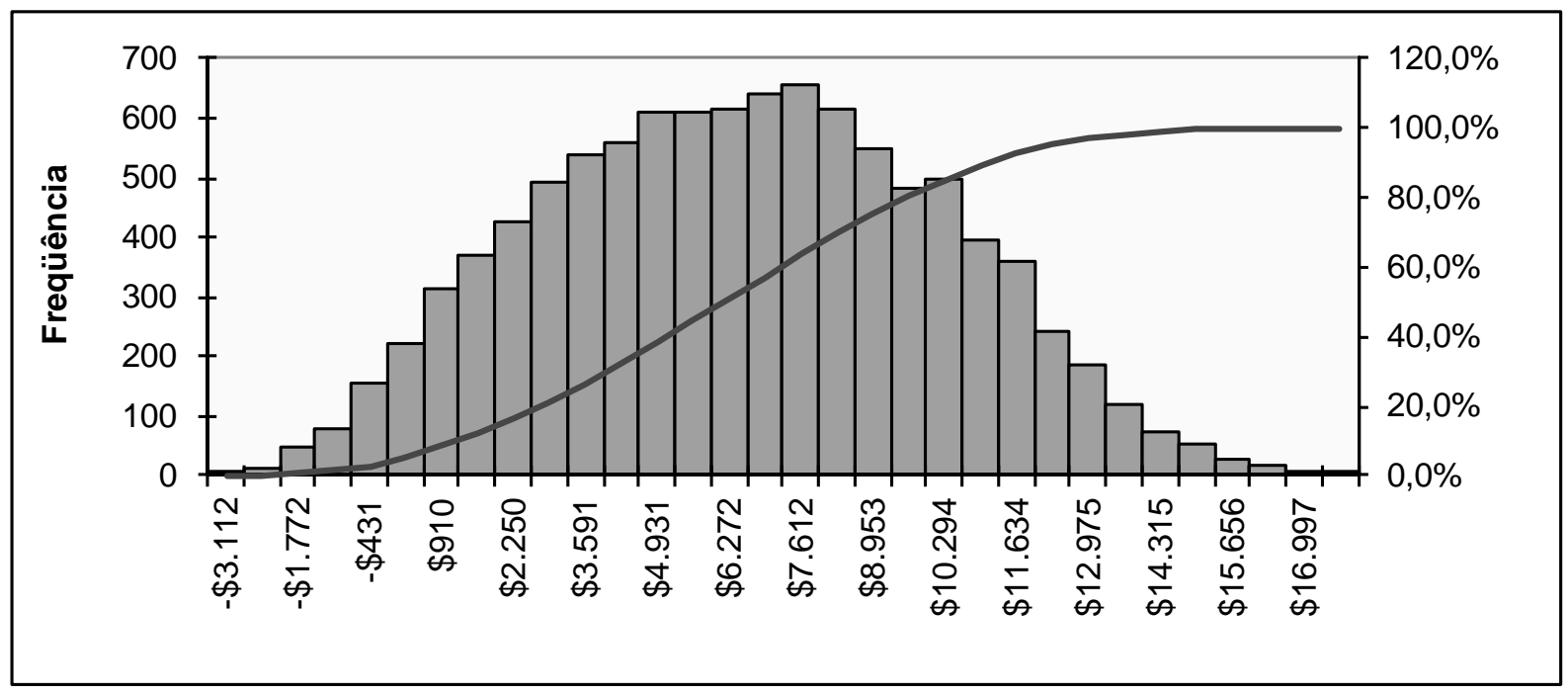

Figure 2 - Distribution of the NPV's

Source: Prepared by the authors (2018).

After all the results, the probability of $95.2 \%$ of the NPV was verified to be greater than zero.

\section{CONCLUSION}

Investment in a photovoltaic solar energy system is a safe investment, regulated by ANEEL itself. The equipment has a service life of up to 30 years and almost requires no maintenance. Brazil is one of the countries with the highest solar radiation in the world. Whenever there is sun, the system will produce electricity.

Photovoltaic systems connected to the grid are an environmentally correct way to produce electricity and an intelligent form of investment. The amount invested in the acquisition of a system connected to the grid becomes an immediate economy in the electricity bill.

In practice, many residential users become energy providers for the network during the day, when there is no one at home or consumption is too low, and become consumers at night, when consumption increases and there is no 
INDEPENDENT JOURNAL OF MANAGEMENT \& PRODUCTION (IJM\&P)

http://www.ijmp.jor.br

v. 10, n. 3, May - June 2019

ISSN: 2236-269X

DOI: 10.14807/ijmp.v10i3.876

generation. The account of the users of the systems connected to the network is also a little different, besides informing the energy consumed, it informs the energy produced during the month.

Gains from the light bill economy are even more evident to the residential consumer, who pays a higher average tariff than commercial and industrial consumers.

Thus, the greater the price of energy that the concessionaire charges the consumer, the greater the value it will give as credit for the sale of energy produced by the consumer. Therefore, in addition to reducing the energy bill, the system connected to the network is a safe way to protect against increases in tariffs and energy bills. These increases in energy tariffs occur annually because of inflation, changes in the climate, such as droughts, and other political and economic factors that consumers who have a system connected to the network need not worry.

The results obtained in this study show that the dimensioned photovoltaic system has a $95.2 \%$ probability of returning with an NPV above zero and this makes it economically feasible.

The methodology used in this article can be replicated to other economic viability analyzes, where the objective is to verify the probability of returning with positive NPV values.

As a suggestion of future work, it is possible to include in this article a multicriteria tool that takes into account besides the NPV, a IRR and payback.

\section{REFERENCES}

BASTIDAS-RODRIGUEZ, J. D. et al. (2017) Quantification of photovoltaic module degradation using model based indicators. Mathematics and Computers in Simulation, v. 131, p. 101-113.

BRANDALISE, N.; CARDOSO, R. (2010) Análise de risco em estudo de viabilidade econômico-financeira com o uso da simulação de Monte Carlo para o comércio de água mineral. XXX ENCONTRO NACIONAL DE ENGENHARIA DE PRODUÇÃO.

DONG, R.; XU, J.; LIN, B. (2017) ROI-based study on impact factors of distributed PV projects by LSSVM-PSO. Energy, v. 124, p. 336-349.

FERREIRA, A. et al. (2018) Economic overview of the use and production of photovoltaic solar energy in brazil. Renewable and Sustainable Energy Reviews, v. 81, n. June 2017, p. 181-191.

GITMAN., L. J. (2013) Princípios de administração financeira. 12. ed. São Paulo: 
INDEPENDENT JOURNAL OF MANAGEMENT \& PRODUCTION (IJM\&P)

http://www.ijmp.jor.br

v. 10, n. 3, May - June 2019

ISSN: 2236-269X

DOI: 10.14807/ijmp.v10i3.876

Pearson Education do Brasil.

HUANG, C.; WANG, L. (2018) Simulation study on the degradation process of photovoltaic modules. Energy Conversion and Management, v. 165, n. March, p. 236-243.

MINISTÉRIO DE MINAS E ENERGIA. (2017) Balanço Energético Nacional.

OLIVEIRA, M. A. (2016) O impacto do ICMS na Geração Distribuída no Brasil. Revista Brasileira de Energias Renováveis, v. 5, n. 3, p. 407-417.

PILLOT, B.; DE SIQUEIRA, S.; DIAS, J. B. (2018) Grid parity analysis of distributed PV generation using Monte Carlo approach: The Brazilian case. Renewable Energy, v. 127, p. 974-988.

ROMERO, D. C.; LOURENÇO, F. R. (2017) Measurement uncertainty of dissolution test of acetaminophen immediate release tablets using Monte Carlo simulations.

Brazilian Journal of Pharmaceutical Sciences, v. 53, n. 3, p. 1-9.

VILLALVA, M.; GAZOLI, J.; FILHO, E. (2009) Comprehensive Approach to Modeling and Simulation of Photovoltaic Arrays. IEEE Transactions on Power Electronics, v. 24, n. 5, p. 1198-1208.

ZOMER, C.; URBANETZ, J.; RÜTHER, R. (2011) Grid-Connected buildingintegrated photovoltaics (BIPV) at low-latitude sites. Building and Environment, v. 46, n. 10, p. $2107-2113$. 